\title{
Algorithms for Olfactory Search across Species
}

\author{
Keeley L. Baker, ${ }^{1,2}$ Michael Dickinson, ${ }^{3}$ Teresa M. Findley, ${ }^{4,5}$ David H. Gire, ${ }^{6}{ }^{\oplus}$ Matthieu Louis, $, 7,9$ ๑Marie P. Suver, ${ }^{10}$ \\ (D)Justus V. Verhagen, ${ }^{1,2}$ (D) Katherine I. Nagel, ${ }^{10}$ and Matthew C. Smear ${ }^{4,11}$ \\ ${ }^{1}$ Department of Neuroscience, Yale School of Medicine, New Haven 06519, Connecticut, ${ }^{2}$ John B. Pierce Laboratory, New Haven 06519, Connecticut, \\ ${ }^{3}$ Division of Biology and Bioengineering, California Institute of Technology, Pasadena 91125, California, ${ }^{4}$ Institute of Neuroscience, University of Oregon, \\ Eugene 97403, Oregon, ${ }^{5}$ Department of Biology, University of Oregon, Eugene 97403, Oregon, ${ }^{6}$ Department of Psychology, University of Washington, Seattle \\ 98195, Washington, ${ }^{7}$ Neuroscience Research Institute, University of Santa Barbara, Santa Barbara 93106, California, ${ }^{8}$ Department of Molecular, Cellular, \\ and Developmental Biology, University of Santa Barbara, Santa Barbara 93106, California, ${ }^{9}$ Department of Physics, University of Santa Barbara, Santa \\ Barbara 93106, California, ${ }^{10}$ Neuroscience Institute, New York University Langone Medical Center, New York 10016, New York, and ${ }^{11}$ Department of \\ Psychology, University of Oregon, Eugene 97403, Oregon
}

Localizing the sources of stimuli is essential. Most organisms cannot eat, mate, or escape without knowing where the relevant stimuli originate. For many, if not most, animals, olfaction plays an essential role in search. While microorganismal chemotaxis is relatively well understood, in larger animals the algorithms and mechanisms of olfactory search remain mysterious. In this symposium, we will present recent advances in our understanding of olfactory search in flies and rodents. Despite their different sizes and behaviors, both species must solve similar problems, including meeting the challenges of turbulent airflow, sampling the environment to optimize olfactory information, and incorporating odor information into broader navigational systems.

Key words: olfactory search; olfactory navigation; active sensing; olfaction; turbulence; memory

\section{Introduction}

Organisms of all sizes use odor to find things. From a bacterium moving up an amino acid gradient to a wolf hunting down its prey, odor tracking can be essential for survival. Olfactory search behavior has been studied in many organisms, including bacteria (Berg, 2001), nematodes (Lockery, 2011), moths (Murlis et al., 1992; Vickers, 2000; Cardé and Willis, 2008), crustaceans (Reeder and Ache, 1980; Atema, 1996; Webster and Weissburg, 2001), fish (Scholz et al., 1976), and birds (Nevitt, 2000; Wallraff, 2004), revealing related but distinct strategies for localizing odor. A thorough survey of olfactory search in all these species is beyond the scope of this review. Here, we will focus on recent work by participants in a Mini-Symposium on "Algorithms for Olfactory Search Across Species," describing new approaches to each of these problems in flies and rodents.

Chemotaxis is best understood in bacteria, which are able to move toward odor without the computing power of networks of neurons. Classical experiments used controlled chemical stimuli and careful measurements of bacterial movement to understand how bacteria chemotax; when bacteria experience an increase in the concentration of an attractive chemical, their probability of turning transiently decreases, causing them to move in a straighter line. When they experience no gradient or go downgradient, the turn probability is maintained at a default value

\footnotetext{
Received Aug. 8, 2018; revised Sept. 15, 2018; accepted Sept. 18, 2018.

The authors declare no competing financial interests.

Correspondence should be addressed to either of the following: Dr. Katherine I. Nagel, Neuroscience Institute, New York University Langone Medical Center, Science Building, 435 E 30th St, 11th Floor, Room 1102, New York, NY, E-mail: katherine.nagel@nyumc.org; or Dr. Matthew C. Smear, Institute of Neuroscience, University of Oregon, Eugene, 0R, E-mail: smear@uoregon.edu.

DOI:10.1523/JNEUROSCI.1668-18.2018

Copyright $\odot 2018$ the authors $\quad 0270-6474 / 18 / 389383-07 \$ 15.00 / 0$
}

(Berg, 2001). This simple algorithm allows unicellular organisms to navigate up an attractive chemical gradient through a biased random walk. The molecular machinery that implements this algorithm is now also well understood: chemoreceptor activation controls phosphorylation of a diffusible messenger protein, CheY, which controls turn probability by interacting with the flagellar motor. Sensory adaption results from the action of a pair of enzymes, CheB and CheR, that control the methylation state of chemoreceptors and confer sensitivity to the temporal dynamics of chemical stimuli (Falke et al., 1997). These classic studies of odor tracking in bacteria provide a template for how behavioral tracking, mathematical modeling, and molecular genetics can be combined to understand a biological system at a deep level (Bi and Sourjik, 2018).

Larger organisms that track odors have more computational resources, neurons and complex sensory systems, to devote to the task, enabling them to overcome more complex problems. One such problem is that odors at large scales form turbulent plumes, consisting of highly complex filaments surrounded by odorless space (Fig. 1). This creates rapid fluctuations in odor concentration, even when the organism is moving toward the source (Crimaldi et al., 2002; Connor et al., 2018). Some organisms, such as moths, crayfish, and crabs, have been shown to use these fluctuations as navigation cues (Mafra-Neto and Cardé, 1994; Koehl et al., 2001; Keller and Weissburg, 2004). Another strategy used by many organisms is to turn upwind when an attractive odor is sensed (Flugge, 1934; Kennedy and Marsh, 1974; Murlis et al., 1992; Steck et al., 2012). This strategy, known as "odor-gated anemotaxis" requires animals to combine information about flow direction, derived from mechanosensation or vision, with information from the olfactory system (Kennedy, 1940; Wasserman et al., 2015; Bell and Wilson, 2016). Thus, odor tracking in 
large organisms often involves integration of multiple sensory modalities.

In addition, olfactory search often entails active sampling of the environment (Fig. 2). For example, rats, moles, dogs, and humans all perform head-scanning during trail tracking (Porter et al., 2007; Khan et al., 2012; Catania, 2013). Drosophila larvae perform a similar headcasting behavior (Gomez-Marin et al., 2011) and may provide a tractable model for understanding the mechanisms and function of this active-sensing behavior in other organisms. Moreover, vertebrates control what, when, and where they smell through sniffing (Mainland and Sobel, 2006; Wachowiak, 2011). New research is uncovering these patterns and providing insight into how they allow animals to gain information about their environments.

Finally, large organisms search over much greater distances, which might require fundamentally different search strategies from those performed by bacteria. One strategy is to use spatial memory to create odor-informed maps of an environment (Jacobs, 2012). When tested with highly predictable sets of resource locations, rodents prefer to memorize source locations and then use this information to perform rapid, probabilistic searches across an environment, only using odor cues to confirm target acquisition when very near to a source (Bhattacharyya and Bhalla, 2015; Gire et al., 2016). A second strategy, exemplified by flying insects, is to use multiple behavioral modules: dispersal, plume tracking, and visual search, to locate a smell, follow it upwind, and hone in on the source (Vickers and Baker, 1994; Cardé and Willis, 2008; Lacey and Cardé, 2011; Lacey et al., 2014; Riffell et al., 2014; van Breugel and Dickinson, 2014; van Breugel et al., 2015). The behavioral strategies used by organisms to search over long distances is an area of active study.

While chemotaxis is a "classical" problem, exciting new technologies offer the promise of understanding this process in larger organisms. First, new technologies are making it possible to visualize olfactory landscapes. For example, lightsheet imaging allows for direct measurements of plume dynamics with high spatial and temporal resolution (Merzkirch, 2012; Connor et al., 2018). Analytical results have also provided new insight into the structure of odors encountered in a turbulent flow (Celani et al., 2014). Big behavioral data (Gomez-Marin et al., 2014) can now be acquired using laboratory assays of restrained (Schulze et al., 2015; Radvansky and Dombeck, 2018) and unrestrained behavior (Gire et al., 2016; Alvarez-Salvado et al., 2018), as well as in field studies (Riffell et al., 2014; Giraldo et al., 2018). New computational tools can be leveraged to understand both olfactory environments and behavioral dynamics (Boie et al., 2018). Finally, genetic tools can be used to reliably identify neurons that may be involved in olfactory navigation and to manipulate these neurons in behaving animals (Kocabas et al., 2012; Tastekin et al., 2015) By combining these technologies, studies of odor tracking in diverse species promise to provide a deep mathematical and circuit understanding of a basic biological problem.

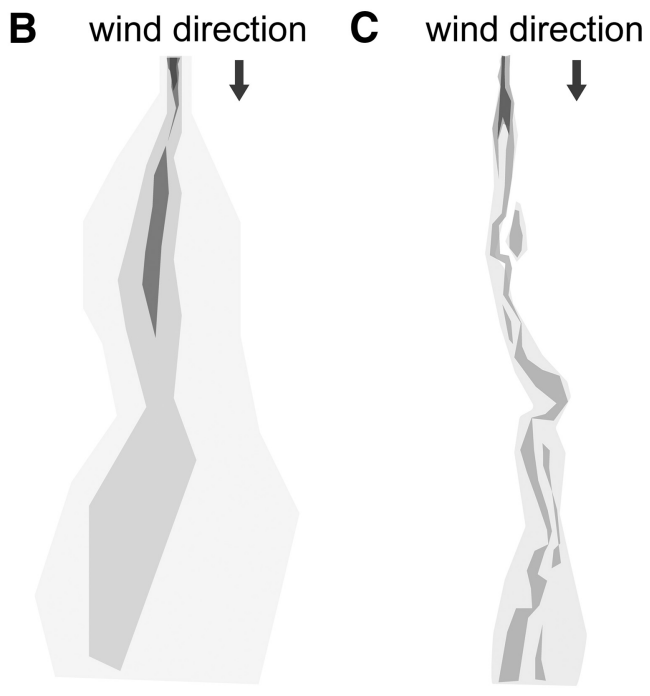

Figure 1. Odor environments vary depending on the distance from a substrate and the air velocity. $A$, A diffusive environment typical of search by substrate-bound organisms, such as fly larvae. $B$, Plume forming near a boundary typical of search by walking Navigating in turbulent environments

Scientists have known for many years that odors at macroscopic scales are turbulent (Murlis et al., 1992; Crimaldi and Kosseff, 2001; Webster and Weissburg, 2001). A simple way to visualize this is to light a match and observe the sinuous and unpredictable pattern the smoke takes as it meanders from the match head. Odors are carried by air currents in much the same way as smoke particles, forming filaments and eddies as they disperse downwind. Although individual turbulent fluctuations are unpredictable, the amount of turbulence, characterized by the Reynolds number, depends in systematic ways on features of the environment (Moore and Crimaldi, 2004; Celani et al., 2014). For example, turbulence grows with distance from a boundary, so turbulence is higher further from the ground. Turbulence also increases with wind velocity. These physical facts mean that a flying fly will encounter the most turbulent odor signals, a walking fly or rodent will encounter smoother, more diffusive signals, and a larva crawling through a substrate will experience relatively little turbulence (Fig. 1).

What kinds of information are present in odor plumes and how do animals use this information? There are several kinds of information that animals might use. For example, the statistics of odor fluctuations vary systematically with position in a plume, and these statistical features may serve as olfactospatial cues (Crimaldi and Kosseff, 2001; Webster and Weissburg, 2001; Boie et al., 2018; Connor et al., 2018). Alternatively, animals could use relatively simple temporal structure, such as the presence or loss of odor, to drive changes in behavior. Most animals have multiple sensors (e.g., two nostrils or two antennae) that allow them to make spatial comparisons between odor concentrations sampled at the same time. Animals can also detect air flow with their antennae (Yorozu et al., 2009) or their whiskers (Yan et al., 2016), and this information can indicate the likely direction of the odor source. Finally, animals could have prior knowledge, obtained through learning or through evolution, about the shape and movement of odor plumes. Algorithms incorporating each of these cues have been proposed by various authors (Kennedy and Marsh, 1974; Borst and Heisenberg, 1982; Baker, 1990; Balkovsky and Shraiman, 2002; Vergassola et al., 2007; Alvarez-Salvado et al., 2018). Recent information-theoretic analysis reveals that plumes 
contain both spatial and temporal information about olfactory target position (Boie et al., 2018).

Numerous studies have reached different conclusions about what types of sensory information animals use to navigate and how they use this information. For example, some studies have suggested that detailed temporal structure in the plume is used to infer odor source location (Mafra-Neto and Cardé, 1994; Ache et al., 2016), whereas others have suggested that animals filter out high-frequency information and respond largely to the envelope of the plume (Alvarez-Salvado et al., 2018). Some algorithms depend on extensive memory and priors about the plume structure (Vergassola et al., 2007), whereas others rely largely on local cues (van Breugel and Dickinson, 2014). Discriminating between these models can be challenging (Pang et al., 2018), as it is often difficult to measure behavioral responses to controlled turbulent stimuli, and it is not always clear how the behavior predicted by each of these models differs. The types of sensory information used by an animal may depend on the type of environment in which it typically searches.

One way to gain insight into the algorithms used by an animal that is navigating in turbulence is to use virtual reality. Virtual reality environments provide a tool to monitor a behaving animal and present a known odor plume simultaneously (Thurley and Ayaz, 2017; Radvansky and Dombeck, 2018). Current virtual odor navigation research by Baker et al. allows real-time exploration of the roles of multimodal sensing and stereo smell during navigation in odor plumes with known structure by rodents. The rodent walks on a ball, which moves a virtual set of nares through an optically imaged horizontal plane of a dynamic plume. During a trial, the animal's locomotion on the ball moves the virtual nares through the virtual plume. The resulting virtual odor concentration dynamics are reproduced in reality using rapid olfactometers. Thus, the rodent receives a faithful simulation of moving through a naturalistic odor plume. Directional wind and light cues can also be provided via a circular array of laminar air flow sources and LEDs, respectively, and imaged plumes of different intermittency can be presented to assess their effects on an animal's navigation strategies (e.g., path tortuosity, velocity, and angle). This approach has revealed strong effects of virtual internaris spacing on the navigation velocity of mice. In addition, active sampling (whisking, sniffing, and nose movements) is also imaged and shows strong modulation during trials. Crosscorrelation analysis can provide helpful insight into the cues guiding the sampling and translational behavior, demonstrating effects of binaral odor cues on an animal's navigation velocity. This paradigm is providing new insight into the cues used by rodents to navigate in odor plumes (Fig. 2).

While scientists disagree about what temporal features of odor are used for turbulent navigation, there is broad agreement that sensing wind direction plays an important role in odor tracking, especially in insects. Much is known about how odor stimuli are encoded and processed by the brains of flies and mice; however, less is known about how wind information is encoded. In flies and other insects, detection of wind direction is known to require antennal mechanoreceptors because mechanically stabilizing the antenna prevents flies from turning upwind when they detect an attractive odor (Wolf and Wehner, 2000; Bhandawat et al., 2010; Alvarez-Salvado et al., 2018). The antennal wind-sensing system is distinct from the well-studied cercal system of crickets, which is located in the insect abdomen (Jacobs et al., 2008). Recent work from Suver et al. has identified neurons in the central brain that process these mechanosensory cues and build a representation of wind direction. Using whole-cell recordings from genetically
A
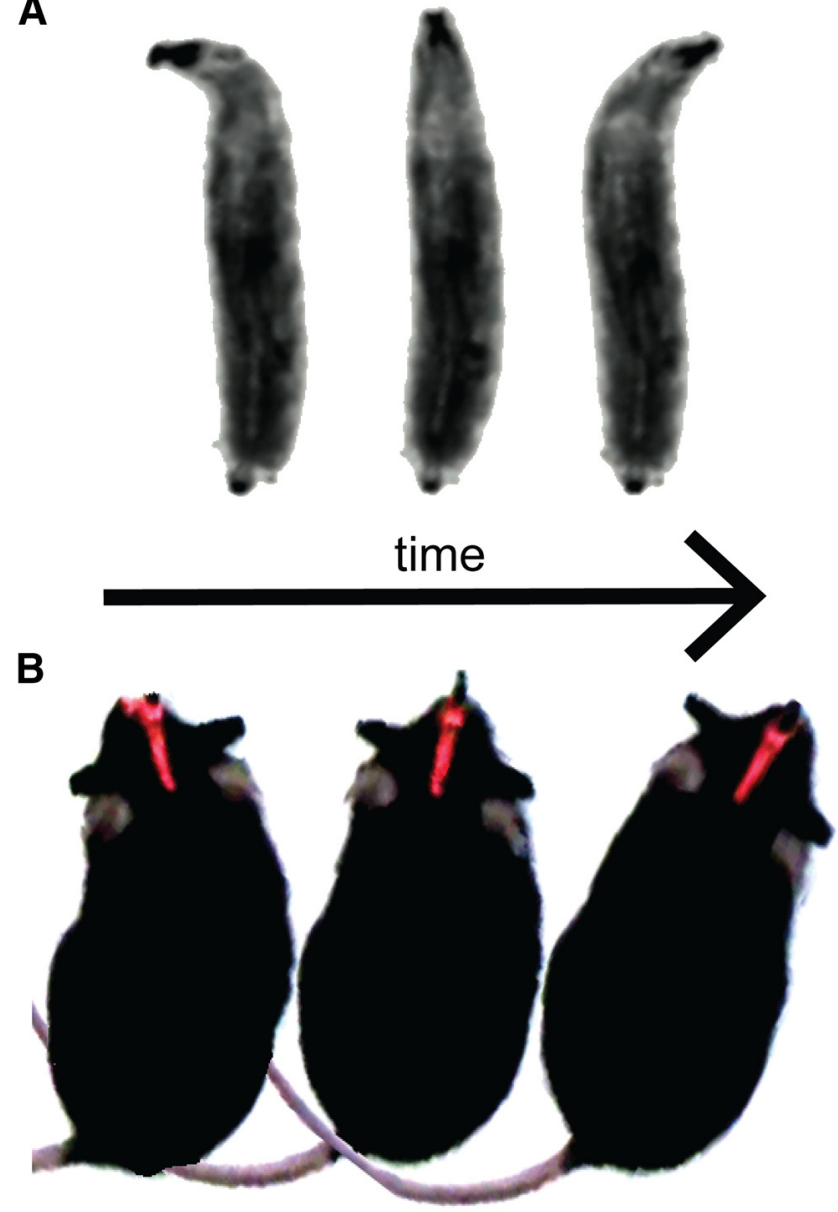

Figure 2. Olfactory search entails active sampling behaviors. These actions optimize sensory input in olfactory scenes. $\boldsymbol{A}$, Head casting behavior in fly larvae. The animal sweeps its head from side to side to effectively sample the odor gradient. $\boldsymbol{B}$, Active sampling behavior in mice. By coordinating head movement with sniffing, mice scan turbulent plumes and guide their locomotion to olfactory targets. A, Adapted with permission from Gomez-Marin and Louis (2012).

identified neurons in Drosophila, Suver et al. recently identified central neurons that integrate information across the two antennae to generate a linear representation of wind direction in azimuth. A combination of intracellular recordings, genetic silencing, and trans-synaptic tracing using trans-Tango (Talay et al., 2017) further revealed that integration of wind stimuli is performed by a broader network of neurons than previously known. This study points toward regions of the brain in which wind and odor information may be combined during behaviors such as odor-gated anemotaxis.

\section{Active sampling of olfactory environments}

Because odor plumes are distributed in space and time, an animal must actively control how it samples the environment, which necessitates tight coordination between sensory input and motor output (Fig. 2).

When introduced to an odor gradient, Drosophila larvae demonstrate reorientation responses (chemotaxis) that rival in precision those of higher-order organisms (Gomez-Marin et al., 2011; Gomez-Marin and Louis, 2012). Olfactory behaviors are directed by a pair of bilaterally symmetrical olfactory organs located at the tip of the head. Remarkably, the sensory information transmitted by a single functional olfactory sensory neuron on either the left or right side of the head is sufficient to direct reorientation ma- 
neuvers (Louis et al., 2008). This finding indicates that larval chemotaxis does not purely result from left-right comparisons, but that it must involve active displacement of the olfactory organs to detect temporal changes in odor concentration.

The chemotaxis behavior of Drosophila larvae is organized in a hierarchy that constitutes a robust reorientation algorithm (Gomez-Marin and Louis, 2014) similar to that of nematodes (Lockery, 2011; Larsch et al., 2015; Roberts et al., 2016). Chemotaxis emerges from an alternation between bouts of forward peristalsis (runs) and stops, usually followed an abrupt change in orientation (stop-turns). Positive odor gradients prolong runs, whereas negative odor gradients promote stop-turns (Gepner et al., 2015; Hernandez-Nunez et al., 2015; Schulze et al., 2015). In addition, larvae continuously align the direction of their runs to the local odor gradient, a process called weathervaning (Iino and Yoshida, 2009; Gomez-Marin and Louis, 2014). Louis et al. show that the sensorimotor mechanism that controls weathervaning relies on the implementation of low-amplitude head sweeps during runs (Fig. $2 A$ ). Once a stop has been triggered, larvae engage in head casts of wider amplitude to scan the local odor gradient. On average, larvae implement fewer than two head casts before initiating a turn (Gomez-Marin et al., 2011), and the directional bias of the first head turn suggests that directional information is accumulated during the preceding run. Although the odor gradient measured in the vicinity of the larval head is typically modest (on the order of 10\%), the stimulus derivative associated with a head cast can be large due to the high speed of the head (on the order of $3 \mathrm{~mm} / \mathrm{s}$, which is three times faster than the speed of forward locomotion). OSN activity modulates the probability that the larva interrupts the ongoing cast. High OSN activity promotes casting, whereas inhibition of the OSN activity induces stopping and a subsequent reversal of the head cast's direction. Louis et al. speculate that head casts achieve two functions. They enable taking snapshots of the odor intensity at different head positions. In addition, rapid movements of the head create large temporal derivatives that strongly modulate the activity of peripheral OSNs.

While invertebrate olfactory sensory neurons are exposed directly to the air, terrestrial vertebrate olfactory sensory neurons are hidden within noses, which odor can access only during inhalation. Thus, breathing determines the time course of olfactory stimulation (Wesson et al., 2008; Shusterman et al., 2011, 2017). Rodents and humans regulate their breathing in response to olfactory stimulation, on a sniff-by-sniff basis (Johnson et al., 2003; Kepecs et al., 2007; Wachowiak, 2011). In addition to this reactive breath control, proactive control plays a central role in olfactory search. Inhalations only draw in a small volume of air relative to the spatial spread of odor plumes and trails. Therefore, to adequately search the olfactory scene, the animal must move its nose in coordination with sniffing (Fig. 2B).

Do animals sniff strategically during olfactory search? For mammals, olfactory search can be subdivided into trail following, in which odor sources are deposited on the nearby ground; and plume following, in which the odor disperses through the air from a distant source (Syrotuck, 1972; Conover, 2007). For trail following, the evidence is clear that rodents and humans structure their behavior in a characteristic way. As they proceed along the trail, they increase their sniff rate while scanning the nose back and forth across the trail, widening the scan path when their nose diverges from the trail (Porter et al., 2007; Khan et al., 2012; Jones and Urban, 2018). For plume following, the structure of search behavior is less clear. In previous studies, animals in familiar arenas adopted memory-guided strategies rather than relying on airborne odor cues (Bhattacharyya and Bhalla, 2015; Gire et al., 2016). Therefore, the behavioral structure of plume following remains unclear.

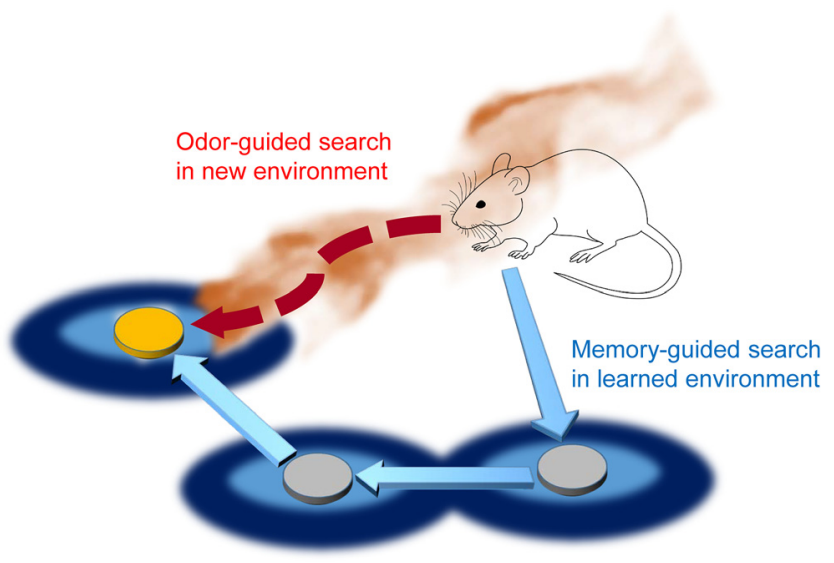

Figure 3. Long-distance olfactory search with a cognitive map. In rodents, olfactory search combines odor-guided and memory-guided navigation. In a new environment, the animal relies on odor cues to find a target. With experience in an environment, the animal can learn the probabilities of target locations and forage more efficiently.

To better understand odor plume following, Findley et al. have designed an unrestrained olfactory search task in which mice must locate an odor source from one of two ports. Importantly, the task requires the mice to commit to a decision at a distance from the port, ensuring that the mice must search the plume to receive reward. Recording respiration and movement reveals when, where, and how rapidly the mouse samples its environment. Mice learn the task rapidly and, after learning, generalize the task rule to other odors. Further, performance of the task does not require stereo olfaction, suggesting that temporal comparison of odor concentration across sniffs is the relevant cue for plume-following under these conditions. Analyzing these rich datasets with machine learning techniques (Wiltschko et al., 2015; Egnor and Branson, 2016) can reveal the behavioral motifs comprising plume search behavior and reveal the underlying sampling strategies. Combining rigorous analysis of this behavior with modern neural circuit recording and manipulation techniques will advance understanding of the neural mechanisms of active sensing.

\section{Long-range olfactory search: the role of memory}

The odor sources animals seek are not always in smellable range. Therefore, animals must supplement their odor-driven search algorithms with long-range navigation systems. Of particular interest is the extent to which olfactory information is held in memory and anchored in allocentric cognitive maps (Fig. 3).

Strong evidence implicates memory, at multiple timescales, in olfactory search. At the shortest timescale, sensory memory enables the brain to track rapid changes in odor concentration, such as might occur when encountering a patch of odor in a turbulent plume. This form of memory confers sensitivity to dynamic odor concentration changes in the subsecond time domain and has been demonstrated in the early olfactory systems of insects (Geffen et al., 2009; Huston et al., 2015; Gorur-Shandilya et al., 2017), crustaceans (Park et al., 2016), and mice (Parabucki et al., 2017). At the intermediate time scale, short-term memory can hold a history of odor encounters over tens of seconds, which is long enough to allow working memory to use the frequency and location of previous odor encounters to create a model of source locations in a turbulent environment (Vergassola et al., 2007; Ache et al., 2016; Pang et al., 2018). Last, long-term memory plays a role in odor-guided navigation by allowing organisms to create odor-informed maps of an environment (Jacobs, 2012). While sensory and short-term memory informs the dynamic interac- 


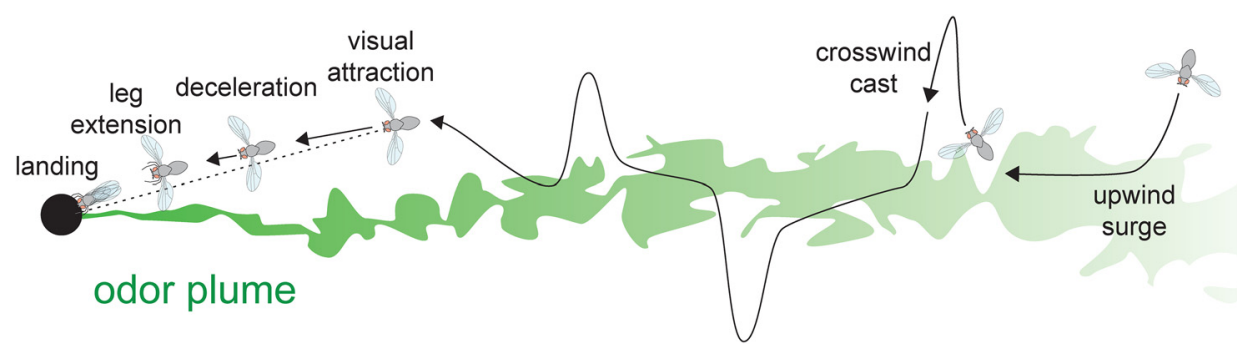

Figure 4. Long-distance olfactory search without a cognitive map. In flying flies, olfactory search behavior emerges from a sequence of chained reflexes. Odor encounter triggers an upwind surge, in which the animal flies parallel to the wind direction. Loss of the plume evokes a crosswind cast, in which the fly flies perpendicular to the direction of flow, which allows the fly to reenter the plume and trigger another upwind surge. As the fly gets close to the target, it becomes attracted to visual objects and executes a sequence of behaviors, including deceleration, leg extension, and landing.

tion of an animal with an odor plume during tracking, long-term memory supports the utilization of prior information to narrow the range of odor-guided searches. The role of long-term memory in narrowing odor-guided searches within larger and more complex environments is an area of active study.

The neural mechanisms of memory use during odor-guided navigation have been investigated across a variety of species (Geffen et al., 2009; Huston et al., 2015; Park et al., 2016; Parabucki et al., 2017). Most models suggest a role for early olfactory circuitry in both sensory and short-term memory (Huston et al., 2015; Park et al., 2016; Gorur-Shandilya et al., 2017), with odor-evoked oscillations and reverberations within these circuits suggested as likely mechanisms for maintaining a history of odor encounters (Laurent and Davidowitz, 1994; Ache et al., 2016). These circuit mechanisms operate over long enough timescales to support navigation within fluctuating plumes at moderate distances (meters). The neural mechanisms used for longer searches across large distances with sparse odor encounters are less well defined, although they could involve a role for more integrative brain structures, such as the hippocampus in mammals, in olfactory working memory (Kesner et al., 2011). Formation of place-odor associations is hippocampal-dependent (Goodrich-Hunsaker et al., 2009) and the odor-guided formation of place cells has been demonstrated both in simulations (Kulvicius et al., 2008) and experimentally in the hippocampus (Zhang and ManahanVaughan, 2015), as has the representation of odor sequences (MacDonald et al., 2013).

\section{Long-range navigation without cognitive maps}

Despite the obvious value of memory in searching previously experienced environments, it seems less useful when an animal must search novel environments for which the animal lacks previous experience (Fig. 4). A series of release and recapture experiments performed in Death Valley, CA indicate that the tiny fruit fly, Drosophila melanogaster, is capable of dispersing over distances of $\geq 10 \mathrm{~km}$. In these experiments, flies were released at one location in the evening and were collected in banana-yeast traps placed in distant oases the next morning. These experiments offer fascinating insight into the process by which an isolated hungry fly, almost literally in the middle of nowhere, finds a new place to feed, mate, and lay eggs. Importantly, given that the flies must traverse an enormous, novel environment, a remembered cognitive map cannot be relevant to this situation.

How did the flies get from point A to point B? Although we cannot know the flies' exact trajectories, all subsequent evidence suggests that this was a multistage process involving several behavior modules (Fig. 4). The first important conclusion is that hungry flies do not simply wait around until an odor plume comes to them; rather, they disperse, presumably in hopes of encountering an odor plume. Initially, the flies likely fanned out in different directions from the release site. New evidence suggests that this dispersal phase is aided by celestial cues, including the position of the sun or moon and the pattern of polarized light in the sky. As with many other insects, flies could use such cues to maintain relatively straight trajectories, so that they cover long linear distances and increase the probability of encountering attractive odor plumes.

When flies do encounter an odor plume, they must quickly abandon their celestial-based heading and initiate the olfactory search algorithms that allow them to track the odor plume to its source. While these search algorithms have not been observed in operation in field studies, our understanding of these search algorithms has been advanced by laboratory wind-tunnel experiments (Budick et al., 2006; van Breugel and Dickinson, 2014). In wind tunnels, flies exhibit behaviors that appear optimized for following the edges of turbulent odor structures. When flies encounter an odor filament, they quickly surge upwind. When they lose the odor, however, they exhibit a substantial delay before they execute a cross-wind cast (van Breugel and Dickinson, 2014). Simulations suggest that the cast delay enhances their ability to follow discontinuous odor plumes because they do not immediately exit the plume whenever they exit an odor packet. Their behavior basically creates a low pass spatial filter of the plume.

Upon tracking the odor plume to its source, the fly must land on it. Because plumes may narrow to fine filaments near their source, the odor plume may no longer be a useful guide. Perhaps to compensate, Drosophila exhibit an increased attraction to small visual objects after detecting attractive odors, which presumably serves to lead them toward potential sources of the odor plume (van Breugel et al., 2014; Saxena et al., 2018). This same behavior is exhibited by mosquitoes (van Breugel et al., 2015), suggesting that it is a quite ancient behavioral module among insects. Thus, the task of finding a new food resource over large spatial scales involves the sequential use and iteration of several behavioral modules involving celestial navigation, plume tracking, and odor-induced visual salience. Further, this chain of behavioral modules can account for the behavior without invoking a need for memory.

In conclusion, animals rely on olfaction both to identify odors and to search for them. An advantage of studying search behavior is that the movement of an animal can be quantified with high spatial and temporal precision, providing a dynamic highresolution read-out of processes that occur within the brain. As we have described in this review, olfactory search involves many fundamental processes, such as multisensory integration, integration of sensation with active sampling movements, and integration of ongoing sensory information with memory and navigation systems. By combining quantitative behavioral measurements with precise stimulus control and manipulations of 
neural circuitry, the study of olfactory search thus promises to provide mechanistic insight into how brains accomplish goaloriented behaviors.

Although much progress has been made in developing tools to study olfactory search, many important questions remain. For example, because odors propagate through airflow, wind-sensing can be useful to olfactory search. How is odor information combined with wind information? Are these signals integrated at a single neural locus or are they combined multiple times? Temporal fluctuations of odor concentration are an important cue to olfactory search. How do brains compute and exploit odor concentration dynamics? Olfactory search inherently entails sensor movements. How do animals integrate olfactory sensation with sampling strategies? In large environments, animals must often search to "pick up the scent" of their olfactory target. How do animals use other sensory cues and memory to navigate these larger environments? We expect these and more questions to become tractable as tools for behavioral tracking, stimulus control, and circuit manipulation continue to improve.

\section{References}

Ache BW, Hein AM, Bobkov YV, Principe JC (2016) Smelling time: a neural basis for olfactory scene analysis. Trends Neurosci 39:649-655. CrossRef Medline

Álvarez-Salvado E, Licata AM, Connor EG, McHugh MK, King BM, Stavropoulos N, Victor JD, Crimaldi JP, Nagel KI (2018) Elementary sensorymotor transformations underlying olfactory navigation in walking fruit-flies. eLife 7:e37815. CrossRef Medline

Atema J (1996) Eddy chemotaxis and odor landscapes: exploration of nature with animal sensors. Biol Bull 191:129-138. CrossRef Medline

Baker TC (1990) Upwind flight and casting flight: complementary phasic and tonic systems used for location of sex pheromone sources by male moth. In Proceedings of the 10th International Symposium on Olfaction and Taste (Døving ED, ed), pp 18-25. Oslo: Graphic Communication System.

Balkovsky E, Shraiman BI (2002) Olfactory search at high Reynolds number. Proc Natl Acad Sci U S A 99:12589-12593. CrossRef Medline

Bell JS, Wilson RI (2016) Behavior reveals selective summation and max pooling among olfactory processing channels. Neuron 91:425-438. CrossRef Medline

Berg HC (2001) Feature article site index motile behavior of bacteria. Physics Today 9:25.

Bhandawat V, Maimon G, Dickinson MH, Wilson RI (2010) Olfactory modulation of flight in Drosophila is sensitive, selective and rapid. J Exp Biol 213:3625-3635. CrossRef Medline

Bhattacharyya U, Bhalla US (2015) Robust and rapid air-borne odor tracking without casting. eNeuro 2:ENEURO.0102-15.2015. CrossRef Medline

Bi S, Sourjik V (2018) Stimulus sensing and signal processing in bacterial chemotaxis. Curr Opin Microbiol 45:22-29. CrossRef Medline

Boie SD, Connor EG, McHugh M, Nagel KI, Ermentrout GB, Crimaldi JP, Victor JD (2018) Information-theoretic analysis of realistic odor plumes: what cues are useful for determining location? PLOS Comput Biol 14:e1006275. CrossRef Medline

Borst A, Heisenberg M (1982) Osmotropotaxis in Drosophila melanogaster. J Comp Physiol 147:479-484. CrossRef

Budick SA, Dickinson MH (2006) Free-flight responses of Drosophila melanogaster to attractive odors. J Exp Biol 209:3001-3017. CrossRef Medline

Cardé RT, Willis MA (2008) Navigational Strategies Used by Insects to Find Distant, Wind-Borne Sources of Odor. J Chem Ecol 34:854-866. CrossRef Medline

Catania KC (2013) Stereo and serial sniffing guide navigation to an odour source in a mammal. Nat Commun 4:1441. CrossRef Medline

Celani A, Villermaux E, Vergassola M (2014) Odor landscapes in turbulent environments. Phys Rev 4:041015.

Connor EG, McHugh MK, Crimaldi JP (2018) Quantification of airborne odor plumes using planar laser-induced fluorescence. Exp Fluids 59:137. CrossRef

Conover MR (2007) Predator-prey dynamics: the role of olfaction. Boca Raton, FL: CRC.
Crimaldi JP, Koseff JR (2001) High-resolution measurements of the spatial and temporal scalar structure of a turbulent plume. Exp Fluids 31:90-102. CrossRef

Crimaldi JP, Wiley MB, Koseff JR (2002) The relationship between mean and instantaneous structure in turbulent passive scalar plumes. J Turbul $3: 1-24$.

Egnor SE, Branson K (2016) Computational analysis of behavior. Annu Rev Neurosci 39:217-236. CrossRef Medline

Falke JJ, Bass RB, Butler SL, Chervitz SA, Danielson MA (1997) The twocomponent signaling pathway of bacterial chemotaxis: a molecular view of signal transduction by receptors, kinases, and adaptation enzymes. Annu Rev Cell Dev Biol 13:457-512. CrossRef Medline

Flügge C (1934) Geruchliche raumorientierung von Drosophila melanogaster. Z Vgl Physiol 20:463-500.

Geffen MN, Broome BM, Laurent G, Meister M (2009) Neural encoding of rapidly fluctuating odors. Neuron 61:570-586. CrossRef Medline

Gepner R, Skanata MM, Bernat NM, Kaplow M, Gershow M (2015) Computations underlying Drosophila photo-taxis, odor-taxis, and multisensory integration. Elife 4. CrossRef Medline

Giraldo YM, Leitch KJ, Ros IG, Warren TL, Weir PT, Dickinson MH (2018) Sun navigation requires compass neurons in Drosophila. Curr Biol 28: 2845-2852.e4. CrossRef Medline

Gire DH, Kapoor V, Arrighi-Allisan A, Seminara A, Murthy VN (2016) Mice develop efficient strategies for foraging and navigation using complex natural stimuli. Curr Biol 26:1261-1273. CrossRef Medline

Gomez-Marin A, Louis M (2012) Active sensation during orientation behavior in the Drosophila larva: more sense than luck. Curr Opin Neurobiol 22:208-215. CrossRef Medline

Gomez-Marin A, Louis M (2014) Multilevel control of run orientation in Drosophila larval chemotaxis. Front Behav Neurosci 8:38. CrossRef Medline

Gomez-Marin A, Stephens GJ, Louis M (2011) Active sampling and decision making in Drosophila chemotaxis. Nat Commun 2:441. CrossRef Medline

Gomez-Marin A, Paton JJ, Kampff AR, Costa RM, Mainen ZF (2014) Big behavioral data: psychology, ethology and the foundations of neuroscience. Nat Neurosci 17:1455-1462. CrossRef Medline

Goodrich-Hunsaker NJ, Gilbert PE, Hopkins RO (2009) The role of the human hippocampus in odor-place associative memory. Chem Senses 34:513-521. CrossRef Medline

Gorur-Shandilya S, Demir M, Long J, Clark DA, Emonet T (2017) Olfactory receptor neurons use gain control and complementary kinetics to encode intermittent odorant stimuli. eLife 6:9. CrossRef Medline

Hernandez-Nunez L, Belina J, Klein M, Si G, Claus L, Carlson JR, Samuel AD (2015) Reverse-correlation analysis of navigation dynamics in Drosophila larva using optogenetics. eLife 4:9. CrossRef Medline

Huston SJ, Stopfer M, Cassenaer S, Aldworth ZN, Laurent G (2015) Neural encoding of odors during active sampling and in turbulent plumes. Neuron 88:403-418. CrossRef Medline

Iino Y, Yoshida K (2009) Parallel use of two behavioral mechanisms for chemotaxis in Caenorhabditis elegans. J Neurosci 29:5370-5380. CrossRef Medline

Jacobs LF (2012) From chemotaxis to the cognitive map: the function of olfaction. Proc Natl Acad Sci U S A 109 [Suppl 1]:10693-10700.

Jacobs GA, Miller JP, Aldworth Z (2008) Computational mechanisms of mechanosensory processing in the cricket. J Exp Biol 211:1819-1828. CrossRef Medline

Johnson BN, Mainland JD, Sobel N (2003) Rapid olfactory processing implicates subcortical control of an olfactomotor system. J Neurophysiol 90:1084-1094. CrossRef Medline

Jones PW, Urban NN (2018) Mice follow odor trails using stereo olfactory cues and rapid sniff to sniff comparisons. bioRxiv 1:24. CrossRef

Keller TA, Weissburg MJ (2004) Effects of odor flux and pulse rate on chemosensory tracking in turbulent odor plumes by the blue crab, Callinectes sapidus. Biol Bull 207:44-55. CrossRef Medline

Kennedy JS (1940) The visual responses of flying mosquitoes. Proc Zool Soc London 109:221-242.

Kennedy JS, Marsh D (1974) Pheromone-regulated anemotaxis in flying moths. Science 184:999-1001. CrossRef Medline

Kepecs A, Uchida N, Mainen ZF (2007) Rapid and precise control of sniffing during olfactory discrimination in rats. J Neurophysiol 98:205-213. CrossRef Medline

Kesner RP, Hunsaker MR, Ziegler W (2011) The role of the dorsal and 
ventral hippocampus in olfactory working memory. Neurobiol Learn Mem 96:361-366. CrossRef Medline

Khan AG, Sarangi M, Bhalla US (2012) Rats track odour trails accurately using a multi-layered strategy with near-optimal sampling. Nat Commun 3:703. CrossRef Medline

Kocabas A, Shen CH, Guo ZV, Ramanathan S (2012) Controlling interneuron activity in Caenorhabditis elegans to evoke chemotactic behaviour. Nature 490:273-277. CrossRef Medline

Koehl MA, Koseff JR, Crimaldi JP, McCay MG, Cooper T, Wiley MB, Moore PA (2001) Lobster sniffing: antennule design and hydrodynamic filtering of information in an odor plume. Science 294:1948-1951. CrossRef Medline

Kulvicius T, Tamosiunaite M, Ainge J, Dudchenko P, Wörgötter F (2008) Odor supported place cell model and goal navigation in rodents. J Comput Neurosci 25:481-500. CrossRef Medline

Lacey ES, Cardé RT (2011) Activation, orientation and landing of female Culex quinquefasciatus in response to carbon dioxide and odour from human feet: 3-D flight analysis in a wind tunnel. Med Vet Entomol 25: 94-103. CrossRef Medline

Lacey ES, Ray A, Cardé RT (2014) Close encounters: contributions of carbon dioxide and human skin odour to finding and landing on a host in Aedes aegypti. Physiol Entomol 39:60-68. CrossRef Medline

Larsch J, Flavell SW, Liu Q, Gordus A, Albrecht DR, Bargmann CI (2015) A circuit for gradient climbing in C. elegans chemotaxis. Cell Rep 12:17481760. CrossRef Medline

Laurent G, Davidowitz H (1994) Encoding of olfactory information with oscillating neural assemblies. Science 265:1872-1875. CrossRef Medline

Lockery SR (2011) The computational worm: spatial orientation and its neuronal basis in C. elegans. Curr Opin Neurobiol 21:782-790. CrossRef Medline

Louis M, Huber T, Benton R, Sakmar TP, Vosshall LB (2008) Bilateral olfactory sensory input enhances chemotaxis behavior. Nat Neurosci 11: 187-199. CrossRef Medline

MacDonald CJ, Carrow S, Place R, Eichenbaum H (2013) Distinct hippocampal time cell sequences represent odor memories in immobilized rats. J Neurosci 33:14607-14616. CrossRef Medline

Mafra-Neto A, Cardé RT (1994) Fine-scale structure of pheromone plumes modulates upwind orientation of flying moths. Nature 369:142. CrossRef

Mainland J, Sobel N (2006) The sniff is part of the olfactory percept. Chem Senses 31:181-196. CrossRef Medline

Masson J-B (2013) Olfactory searches with limited space perception. Proc Natl Acad Sci U S A 110:11261-11266. CrossRef Medline

Merzkirch W (2012) Flow visualization. New York: Elsevier.

Moore P, Crimaldi J (2004) Odor landscapes and animal behavior: tracking odor plumes in different physical worlds. J Marine Syst 49:55-64. CrossRef

Murlis J, Elkinton JS, Cardé RT (1992) Odor plumes and how insects use them. Annu Rev Entomol 37:505-532. CrossRef

Nevitt GA (2000) Olfactory foraging by Antarctic procellariiform seabirds: life at high Reynolds numbers. Biol Bull 198:245-253. CrossRef Medline

Pang R, van Breugel F, Dickinson M, Riffell JA, Fairhall A (2018) History dependence in insect flight decisions during odor tracking. PLoS Comput Biol 14:e1005969. CrossRef Medline

Parabucki A, Bizer A, Morris G, Smear MC, Shusterman R (2017) Odor concentration change detectors in the olfactory bulb. bioRxiv. Advance online publication. Retrieved Apr. 11, 2017. doi: 10.1101/114520.

Park IJ, Hein AM, Bobkov YV, Reidenbach MA, Ache BW, Principe JC (2016) Neurally encoding time for olfactory navigation. PLoS Comput Biol 12:e1004682. CrossRef Medline

Porter J, Craven B, Khan RM, Chang SJ, Kang I, Judkewitz B, Volpe J, Settles G, Sobel N (2007) Mechanisms of scent-tracking in humans. Nat Neurosci 10:27-29. CrossRef Medline

Radvansky BA, Dombeck DA (2018) An olfactory virtual reality system for mice. Nat Commun 9:839. CrossRef Medline

Reeder PB, Ache BW (1980) Chemotaxis in the Florida spiny lobster, Panulirus argus. Anim Behav 28:831-839. CrossRef

Riffell JA, Shlizerman E, Sanders E, Abrell L, Medina B, Hinterwirth AJ, Kutz JN (2014) Flower discrimination by pollinators in a dynamic chemical environment. Science 344:1515-1518. CrossRef Medline

Roberts WM, Augustine SB, Lawton KJ, Lindsay TH, Thiele TR, Izquierdo EJ, Faumont S, Lindsay RA, Britton MC, Pokala N, Bargmann CI, Lockery SR (2016) A stochastic neuronal model predicts random search behaviors at multiple spatial scales in C. elegans. eLife 5:489. CrossRef Medline

Saxena N, Natesan D, Sane SP (2018) Odor source localization in complex visual environments by fruit flies. J Exp Biol 221:jeb172023. CrossRef Medline
Scholz AT, Horrall RM, Cooper JC, Hasler AD (1976) Imprinting to chemical cues: the basis for home stream selection in salmon. Science 192: 1247-1249. CrossRef Medline

Schulze A, Gomez-Marin A, Rajendran VG, Lott G, Musy M, Ahammad P, Deogade A, Sharpe J, Riedl J, Jarriault D, Trautman ET, Werner C, Venkadesan M, Druckmann S, Jayaraman V, Louis M (2015) Dynamical feature extraction at the sensory periphery guides chemotaxis. Elife 4. CrossRef Medline

Shusterman R, Smear MC, Koulakov AA, Rinberg D (2011) Precise olfactory responses tile the sniff cycle. Nat Neurosci 14:1039-1044. CrossRef Medline

Shusterman R, Sirotin YB, Smear MC, Ahmadian Y, Rinberg D (2017) Sniff invariant odor coding. bioRxiv. Advance online publication. Retrieved Aug. 11, 2017. doi: 10.1101/174417.

Steck K, Veit D, Grandy R, Badia SB, Mathews Z, Verschure P, Hanson BS, Knaden M (2012) A high-throughput behavioral paradigm for Drosophila olfaction: the Flywalk. Sci Rep 2:361. CrossRef Medline

Syrotuck WG (1972) Scent and the scenting dog. Machanicsburg, PA: Barkleigh Publications.

Talay M, Richman EB, Snell NJ, Hartmann GG, Fisher JD, Sorkaç A, Santoyo JF, Chou-Freed C, Nair N, Johnson M, Szymanski JR, Barnea G (2017) Transsynaptic mapping of second-order taste neurons in flies by transTango. Neuron 96:783-795.e4. CrossRef Medline

Tastekin I, Riedl J, Schilling-Kurz V, Gomez-Marin A, Truman JW, Louis M (2015) Role of the subesophageal zone in sensorimotor control of orientation in Drosophila larva. Curr Biol 25:1448-1460. CrossRef Medline

Thurley K, Ayaz A (2017) Virtual reality systems for rodents. Curr Zool 63:109-119. CrossRef Medline

van Breugel F, Dickinson MH (2014) Plume-tracking behavior of flying Drosophila emerges from a set of distinct sensory-motor reflexes. Curr Biol 24:274-286. CrossRef Medline

van Breugel F, Riffell J, Fairhall A, Dickinson MH (2015) Mosquitoes use vision to associate odor plumes with thermal targets. Curr Biol 25:21232129. CrossRef Medline

Vergassola M, Villermaux E, Shraiman BI (2007) "Infotaxis" as a strategy for searching without gradients. Nature 445:406-409. CrossRef Medline

Vickers NJ (2000) Mechanisms of animal navigation in odor plumes. Biol Bull 198:203-212. CrossRef Medline

Vickers NJ, Baker TC (1994) Reiterative responses to single strands of odor promote sustained upwind flight and odor source location by moths. Proc Natl Acad Sci U S A 91:5756-5760. CrossRef Medline

Wachowiak M (2011) All in a sniff: olfaction as a model for active sensing. Neuron 71:962-973. CrossRef Medline

Wallraff HG (2004) Avian olfactory navigation: its empirical foundation and conceptual state. Anim Behav 67:189-204. CrossRef

Wasserman SM, Aptekar JW, Lu P, Nguyen J, Wang AL, Keles MF, Grygoruk A, Krantz DE, Larsen C, Frye MA (2015) Olfactory neuromodulation of motion vision circuitry in Drosophila. Curr Biol 25:467-472. CrossRef Medline

Webster DR, Weissburg MJ (2001) Chemosensory guidance cues in a turbulent chemical odor plume. Limnol Oceanogr 46:1034-1047. CrossRef

Wesson DW, Carey RM, Verhagen JV, Wachowiak M (2008) Rapid encoding and perception of novel odors in the rat. PLoS Biol 6:e82. CrossRef Medline

Wiltschko AB, Johnson MJ, Iurilli G, Peterson RE, Katon JM, Pashkovski SL, Abraira VE, Adams RP, Datta SR (2015) Mapping sub-second structure in mouse behavior. Neuron 88:1121-1135. CrossRef Medline

Wolf H, Wehner R (2000) Pinpointing food sources: olfactory and anemotactic orientation in desert ants, Cataglyphis fortis. J Exp Biol 203: 857-868. Medline

Wystrach A, Lagogiannis K, Webb B (2016) Continuous lateral oscillations as a core mechanism for taxis in Drosophila larvae. Elife 5:417. CrossRef Medline

Yan SW, Graff MM, Bresee CS, Man YB, Hartmann MJ (2016) Whiskers aid anemotaxis in rats. Sci Adv 2:e1600716. CrossRef Medline

Yorozu S, Wong A, Fischer BJ, Dankert H, Kernan MJ, Kamikouchi A, Ito K,Anderson DJ (2009) Distinct sensory representations of wind and nearfield sound in the Drosophila brain. Nature 458:201-205. CrossRef Medline

Zhang S, Manahan-Vaughan D (2015) Spatial olfactory learning contributes to place field formation in the hippocampus. Cereb Cortex 25:423432. CrossRef Medline 